\title{
DO YOU CARE YOUR LOCAL LANGUAGE?
}

\author{
Isna Indriati \\ MTsN-2 Palangka Raya \\ isna_iin@yahoo.com
}

\begin{abstract}
The blooming of the English usage every time and everywhere may exterminate the use of local languages. It is also supported by the increase of migration out of or into areas of Indonesia that makes people tend to use Indonesian often than local languages. This might be caused by the personal inability to communicate with indigenous people by their native languages. Besides, the cross cultural marriage also results on the difficulties to determine which mother tongue they introduce to their children. In fact, multicultural condition demands people to use Indonesian frequently. This condition shows that Indonesian works greatly because it is national language. In contrast, the interest of using and learning local language may decrease gradually. This study was conducted to find out whether Indonesian EFL learners of Dayakese background have highly concern to their local language. The data were gathered through direct observation, interviews, and questionnaire. The data collected, then, were analyzed rigorously using descriptive statistics. The findings show that most students have low affection towards their local language, even those who are from indigenous people. Local language is less valued than Indonesian, since they are from different ethnic. Indonesian, then, is highly valued for both formal and informal communication, whether or not it is used as language learning instruction. It is recommended that there is a need for the government to encourage the use or learning of local language. Further, the educational language policy makers together with the Art and Tourism Department consider the promoting local language as a language instruction and a subject. Thus, there will be any ways to keep the ethnicity of Indonesia.
\end{abstract}

\section{Keywords: local language, EFL learners, Dayakese, local language endangerment}

"I speak my favorite language because that's who I am. I teach my children my favorite language because I want them to know who they are". The reason I do this thing is that I respect my ethnicity culture, from which I learn to be a civilized woman with all the politeness in my language. As a Javanese people, it is much recommended for every wife to speak high level local language in order to show her respect to her parents and husbands. Another requirement for women is to give a good example for their children to speak politely in their local language. Thus, the use of local language, especially mother tongue, to communicate with children at home is also meant to introduce them their indigenous language and its culture as well.

Living in the society with different ethnicity provides a great chance to know other cultures. However, it requires great capability to adapt with those cultures. Although Indonesian has been recognized as national language and being used by almost all people, some of them keep using their local language to communicate with others from the same ethnic. In one side, this becomes a good habit in which people are fond of speaking in indigenous language 
respectfully. In other side, people from other ethnics must be determined because they cannot communicate with. Therefore, positively people have great intention to keep their culture and identity as well.

It is also called second language after mother tongue. It is important for educational setting since it is impossible to use many local languages to deliver the learning based on the students' background. Although Indonesian is a second language, most people use it as daily language. There are a few numbers of people who are able to communicate with their native language. Indonesian and native languages are interrelated. In one side, native languages enrich Indonesian vocabulary. In other side, Indonesian may endanger native languages if its development out of control. As the effect, there will be a few families who keep using their local language at home when they live at the new resettlement joined with other families from different ethnics. They tend to use the majority language used by the community in order to socialize with other people in their surroundings.

\section{METHOD}

This study used descriptive qualitative method. It was aimed at finding whether or not nowadays people, especially the youth, care about their native language. The researcher employed three instruments to obtain the data. Firstly, the questionnaires were delivered to gather quantitative data. It was conducted through a survey research. The survey was conducted in Junior High School in Palangka Raya. There are 47 SMPs and 13 MTSs within 13,490 students. However, the researcher chose probability random sampling by applying two-stage cluster sampling was under the consideration that they were representatives of the population (Ross, n.d:18). Seven big schools were, then, chosen. They consist of 4,602 students. In order to limit the time and cost consumption, the data from the questionnaire is, then, collected from 920 students. The first questionnaire was to elicit the respondents who have been living at this city within Dayakese as local language. It was to know their daily languages among the options given. The second was expected to grasp the students' attitudes towards their local language usage at home and school in daily interaction. So far, it was the tool which can reveal their awareness of their local language.

Secondly, direct observation was conducted in 22 classrooms. It was to discover the rise of local language utterances in the classroom during the learning process. Thirdly, in-depth interview with English teachers and some students was also carried out to dig up the information about their awareness of native (local) language contrasted to Indonesian language development.

\section{RESULTS AND DISCUSSION}

The analysis on the questionnaire provided important information on students' periods of living in the setting, by neglecting their ethnical backgrounds. This is assumed that whenever a person comes to a new society which has different culture mainly local language, it is required an ability of adaptation. This will help his/her to get used to the new situation. The data shows that $65 \%$ of the respondents live in Palangka Raya since they were born. 18\% of them live around 5 to 10 years and the rest $15 \%$ less than 5 years.

\section{Daily Language Preferences}

The result on the respondents' daily language preference shows that most of them, $40 \%$, use Indonesian as their daily language to communicate with their parents at home. It is also shown that they use Indonesian (56\%) and Banjarese (37\%) to interact with their friends at school. Indonesian holds the important role as a means of communication between teachers and students in formal institutions, mainly schools. It is shown from the result that $98 \%$ of the respondents use Indonesian to communicate with their teachers.

Figure 1 shows the result of the respondents' capability on comprehending the local language 
utterances. Most respondents can understand Dayakese language well. However, it is far different from their capability to speak that language. $38 \%$ of the respondents can speak Dayakese fluently. 36\% of them cannot speak and the rest use it when their friends ask to do so. Their capability may depend on their daily communication. When they use Dayakese to speak with their parents, they state that they are able to speak that local language. In contrast, those who do not use Dayakese as daily communication, they are not able to speak that language well.

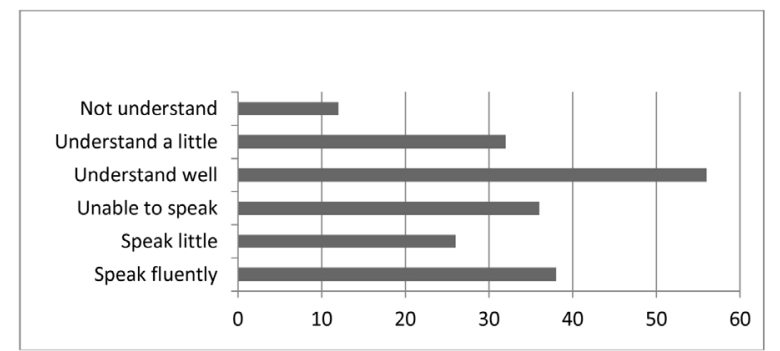

Figure 1. Dayakese Comprehension and Speaking Ability

Concerning with the respondents' capability in English comprehension, $61 \%$ of them stated that they understand English well. The rest, $39 \%$ of the respondents have lower capability in English understanding. Those who have higher ability in English are fond of English as language instruction. The lower one is getting easy with the use of Indonesian as the language instruction for English learning. Overall, Indonesian remains the important means as language instruction and connection at school. It is shown from the result that $89 \%$ respondents chose Indonesian as language instruction for all subjects. $11 \%$ of them like Dayakese and Banjarese. The rest (4\%) likes a mixed language. The result of the observation proves that the teachers may use two languages at the same time. It is under the consideration that the code switching even translation may be needed to lead the students understand the instruction.

\section{Attitude towards Dayakese Local Language}

The data obtained from the second questionnaire will draw the students' attitudes towards their local language. Table 1 shows that the most respondents $(63 \%)$ do not agree with the use of Dayakese local language which is used as a means of daily communication. It is quite the same as the use language instruction during learning process. $47 \%$ of the respondents send their voting for their disagreement for the use of Dayakese. However, the majority of respondents respond positively to the inclusion of Dayakese as compulsory subject at school. It is confirmed that Dayakese is hard to understand because it is rarely used to communicate. This proved by the result of the interview that most of the students prefer using Indonesian and Banjarese to make connection with others, to chat with friends, to talk with parents or to discuss something with teachers. Yet, most of respondents do not agree with the statement that English is easier than Dayakese. There is $6 \%$ of them set their strong agreement and $25 \%$ fairly agree. It is assumed that they enjoy learning English than Dayakese because of their need. Conversely, in terms of language importance, most of respondents do not agree that English takes the most important role than Dayakese. Further, nearly all the respondents agree with the statement that local language represents personal identity though they do not fully agree that their local language capability start to diminish. 
Table 1. Students' Opinions on the Dayakese Usage in Daily Interaction

\begin{tabular}{lllll}
\hline Statement & SA & A & DA & SDA \\
\hline Dayakese usage to communicate at school & 3 & 25 & 63 & 9 \\
\hline Dayakese for lang.instruction & 9 & 28 & 47 & 14 \\
\hline Dayakese as compulsory subject & 39 & 46 & 13 & 1 \\
\hline Dayakese is hard bec.rarely used & 11 & 60 & 21 & 7 \\
\hline English is easier than Dayakese & 6 & 25 & 57 & 12 \\
\hline English is more important than Dayakese & 7 & 28 & 48 & 16 \\
\hline Local lang.ability shows identity & 31 & 50 & 13 & 2 \\
\hline Local lang.ability decrease nowadays & 12 & 30 & 39 & 15 \\
\hline
\end{tabular}

\section{Dayakese Local Language Endangerment}

Research has found that most of Junior High School students prefer using Indonesian and popular language, Banjarese, for daily communication. They recognize the importance of Dayakese local language as one of the important asset of indigenous culture. The various local language background of the students draws them to use Indonesian as a main communication means both formal and informal. This findings illustrate the condition of Dayakese as local language. Its position nowadays may be in endangered language as Ad Hoc Expert Group (2003) states that a language is endangered when it is on a path toward extinction. Further, a language is in danger when its speakers are reluctantly to use it, or use it infrequently in communicative domains, and "cease to pass $i^{\prime \prime}$ on from one generation to the next, so there are no new speakers, adults or children. Wurm cited in Janse (2003:ix) categorizes 5 levels of language endangerment. They are:

1. Potentially endangered if the children start preferring the dominant language and learn obsolescent language imperfectly.

2. Endangered if the youngest speakers are young adults and there are no or very few child speakers.

3. Seriously endangered if the youngest speakers are middle-aged or past middle age.

4. Terminally endangered or moribund if there are only a few elderly speakers left.

5. Dead when there are no speakers at all. In short, Dayakese is a potentially endangered language because the users, mainly the young, prefer using Banjarese and Indonesian for daily communication.

How can Dayakese local language in the process of dying? The fact, Dayakese is not taught to children in all elementary schools in Palangka Raya. There are only state elementary schools under Education and Culture Department that employ Dayakese as local subject. It disappears from the Junior high School curriculum too. It is replaced by Art and Culture subject which comprises Dayak culture. However, based on the in-depth interview to students, the Art and Culture subject mostly discusses Dayak culture globally. Moreover, the teachers never use Dayakese as the language instruction for tht subject, but Indonesian or English. This condition verifies the Krauss' statement in Hoffman (2009:12) that endangered languages are those that are currently still being learned by children, but that will no longer be taught to children within the century. Soon, any languages will come into a phase being in danger if there is not any effort to regenerate them to the young speakers. Without adequate documentation, a language that is extinct can never be revived.

\section{English, Indonesian, and Dayakese}

What makes a language endanger? There are many reasons why a language might become endangered or even extinct. Globalization is one of the main causes of language endangerment. It has constructive and destructive sides. This phenomenon changes the language become unifying and separating factors. English, then, 
becomes the core of globalization. It is needed to interact with others in all over the world to improve knowledge, and science. Dealing with English as a foreign language taught in Indonesia, teachers and students provide a big portion of their time to completed learning. It is under consideration that this language is not spoken by most people in Indonesia for daily communication. In fact, this influences on language shift.

Globalization also refers to the growth of many media, printed and electronic, in which English along with Indonesian become dominant language. For the most part, radio and television programs have been broadcast in just a handful of languages. According to Hoffman (2009:17) English was the language of 70 percent of the world's mail and 60 percent of radio and television broadcasts. Krauss as cited in Hoffman (2009) calls television as "cultural nerve gas" because it flows the majority language and culture into the homes of indigenous people. It is able to accelerate the rate at which they abandon their own languages and cultures. Technology, for the most part, is not available in indigenous languages, requiring these speakers to use the majority language if they want to make use of technology - especially the Internet - or have access to mass media.

Generally, there are four essential factors that lead language endangerment. Hoffman (2009:14-17) describes the first factor is the physical loss of speakers that is because of natural disasters. Sallabank (2010) adds that natural disasters may be famine, earthquake, and tsunami. Besides, war and genocide are among the physical artificial disaster. Secondly, the disintegration of the language community becomes the effect of displacement or the assimilation into the dominant population. This phenomenon may arise the effect of rural poverty leads to migration to cities and further field. If the local economy improves, tourism may bring speakers of majority language like English and French. It influences the process of mastering the majority language which may set indigenous language and culture aside. Thirdly, the homogenizing effects of mainstream media occur in the form of dominant-language television, radio, and print media. Fourth is the force on abandonment of the language through overt suppression and the use of dominant language schools.

Among the above factors, the third and the fourth factors may become the most happening at home or school environment. The evident, in Indonesian context, especially in Palangka Raya, shows most schools require students to speak Indonesian well. Among their friends, the students prefer using Banjarese as the dominant language to interact with. Banjarese is easier to adapt because the syntax and most vocabulary are similar to Indonesian. Besides, the choice those two languages as communicative language is that the students are from various background. Moreover, those dominant languages are often brought to and used at home.

In relation with this condition, most parents are eager to let their children learning the majority language as English, Arabic, or Spanish. For economically reason, teaching those languages to their children will help them to find jobs and be successful. Children also have a big role in this process, and often it drives them to make a choice to stop learning their ancestral language and use the dominant language exclusively. Moreover, they take any private courses in order that they could master the target language better. Unfortunately, this condition leads parents' misunderstanding that when children have learned the majority language, they must also stop using their own native language. It results parents' fear of speaking native language at home because it will slow the child's acquisition of the more economically valuable language.

Here are some evident of the use of English at various field. In Indian, Salabank (2003:55) describes that the government requires Indian children attend boarding schools but where they would be punished for speaking anything other than English. Although they did not know 
any English when they arrived at the schools, they would be punished for using their native language. Such experiences led many of the boarding school students to develop negative attitudes toward their own native languages. Some people said that language will told for years that your language is useless, and having your teacher respond to any attempt to speak the language by actually causing you physical pain, surely will have lasting effects on how you view that language. Negative opinions and low prestige become a major cause of language endangerment.

At last, nowadays phenomenon is that English becomes the primary language used for international commerce, science and technology, and higher education. Newman (2003:4) shows the empirical study "exotic" languages takes minor position in linguistics, because most researches concern with English, linguistics, second language learning and acquisition, and sociolinguistics. Most researchers are not attracted by the idea of "exotic" language because they do not want to go to the field.

\section{Effort in Maintaining Local Language}

Language has beneficial function in reserving cultural heritage. Language can reflect the attitude of the speakers, implicating for identity, communication, social integration, education and development. Through language, a nation can develop greater and better because of its world's rich tapestry of cultural diversity, opportunities, traditions, and memory. Sallabank (2003:60) supports that languages are often seen as symbols of ethnic and national identity. The disappearance of a language means a huge scientific loss, in which a unique way of looking at the world also disappears. Shortly, multilingual nation decreases its cultural diversity gradually without any documentation of language.

In order to preserve the local language, the join of linguists, educators, native speakers are greatly needed. Woodbury (n.d:2) suggests that linguists keeps trying to learn as much about native (local) languages as possible so that even if the language disappears, all knowledge of the language will not disappear at the same time. Then, researchers make videotape, audiotape, written records of language use in both formal and informal setting along with the translation. Hoffman (2009:17) advises, first, that elevating the prestige of a language makes the speakers are supported to feel that it is valuable and important to maintain their native. Second advice is to enhance the prestige of a language by using indigenous language for broadcast program so that speakers will have great opportunity to hear their language both for entertainment and higher economic and social standing.

Other revitalization effort can be done in classroom by conducting bilingual learning in national and local language, or establishing local language as local subject at school. Lauder (2011:327) suggests that the effort of inclusion local language as compulsory subject needs great support from several stake holders, mainly the government. Further, it must be any consideration that only those local languages who have great number of speakers that will be implemented in school curriculum. The policy of the use local language as language instruction has been recommended in pedagogical linguistic (Lauder, 2011:322). However, the choice of using Indonesian as language instruction cannot be avioded because of multicultural background. Such recommendation should get great encouragement in terms of local language materials and teachers' competence.

Another way to explore cultural diversity in order to insist on traditional heritage is concerned. Arising interesting activities that attract students as youth should also get approval from the authority. An example is provided by Lauder (2011:328) that Javanese youth make various innovative work by creating picture or painting funny characters of local folklore or flora and fauna. They are displayed on T-shirt with traditional writing of local language, such as Aksara Jawa, or Wayang characters. Such 
efforts can be figured out to revitalize Dayak culture, especially its local language.

\section{CONCLUSION}

This research attempted to find out students' attitudes toward mother tongue usage in daily communication, both at home and school in Junior High School context. It was found out that most students use Indonesian, the national language as the main tool for interaction, especially at school environment. Another popular language, Banjarese, become the main choice since it has simple syntax and vocabulary that are quite the same as Indonesian. The cultural point of view that Dayakese is a local language being in danger, the students respond positively by sending their agreement that Dayakese may become compulsory subject in order to keep that local language growing. An important suggestion from English teachers who are indigenous people is that there should be a

\section{REFERENCES}

Ad Hoc Expert Group. (2003). Language Vitality and Endangerment. International Expert Meeting on UNESCO Programme Safeguarding of Endangered Languages Paris, 10-12 March 2003.

Janse, M. \& Sijmen, T. (2003). Language Death and Language Maintenance: Theoretical, Practical, and Descriptive Approaches. Amsterdam: John Benjamins Publishing Co.

Lauder, M.R. (2011). Kepedulian terhadap Keberagaman melalui Revitalisasi Bahasa Minoritas. In Riris K. TohaSarumpaet (Eds). Ilmu Pengetahuan proper material for Dayakese local language with accurate scripts. It is to avoid the rise of language error.

Finally, the result of this study provides teachers with a pedagogical basis to enable them to understand and make use of the role of indigenous language as language instruction in the classroom. Further, it is recommended to the authority of the city in order to take account on the revitalization effort of Dayakese local language, especially in the elementary and secondary school curriculum. The relevant parties, as Education and Culture Department and Art and Tourism Department, are expected to do essential efforts by growing a number of conferences, workshops, and publications which offers support for individuals, schools, and communities who are trying to preserve local language. Making a connection with schools, teachers, and parents in order to build Dayakese speaking habit will also result better.

Budaya dan Tanggung Jawabnya. Jakarta: Penerbit Universitas Indonesia.

Ross, K.N. (n.d). Sample Design for Educational Survey Research. UNESCO. (Online). (http://www.sacmeq.org/downloads/ modules/module3.pdf), accessed on August 12, 2014.

Sallabank, J. (2010). Language Endangerment: Problems and Solutions. Source: eSharp, Special Issue: Communicating Change: Representing Self and Community in a Technological World, 50-58.

Woodbury, A.C. (n.d). What is an Endangered 7. Language? Betty Binner, ed. Suite: Linguistics Society of America. 
62 | Journal on English as a Foreign Language, Volume 4, Number 2, September 2014 